\section{BRS 372 and BRS 416: high-yielding cotton cultivars with multiple disease resistance}

\author{
Nelson Dias Suassuna ${ }^{1^{*}}$, Camilo de Lelis Morello ${ }^{1}$, João Luís \\ da Silva Filho ${ }^{1}$, Murilo Barros Pedrosa ${ }^{2}$, Fabiano José Perina ${ }^{1}$, \\ Fernanda Oliveira da Cunha Magalhães ${ }^{1}$, Valdinei Sofiatti ${ }^{1}$ and \\ Fernando Mendes Lamas ${ }^{3}$
}

\begin{abstract}
BRS 372 and BRS 416 are cotton cultivars with high lint yield and genetic resistance to the main cotton diseases in Brazil, particularly to Ramularia Leaf Spot. They have stable yields, good fiber quality and can contribute to a sustainable cotton disease management in tropical environments.
\end{abstract}

Keywords: Gossypium hirsutum, disease resistance, lint yield.

\section{INTRODUCTION}

Cotton (Gossypium hirsutum L.) is an important commodity in the global agricultural economy. Since the 1980's, the cotton-growing area in the Brazilian savannah (cerrado) was significantly increased, mainly due to the development of genetically improved cotton cultivars, with e.g., higher lint yield and adapted to the cerrado, and because of adjustments and enhanced production systems (Silva Neto et al. 2016). Currently, more than $90 \%$ of the Brazilian cotton-growing areas are located in this ecosystem. Particular characteristics of these production systems are extensive areas, high inputs and use of high yielding cultivars that are frequently susceptible to tropical diseases (Ferreira Filho and Alves 2007). In this scenario, diseases previously considered secondary or new diseases, e.g., Ramularia Leaf Spot (RLS), caused by the fungus Ramulariopsis pseudoglycines, can become epidemic. The latter cotton disease has a high economic relevance since up to eight fungicide applications per season are required to control it in a production area of more than 1.000,000 hectares (Silva et al. 2019).

In Brazil, much effort has been invested in developing new cotton cultivars (Morello et al. 2010, Morello et al. 2012, Morello et al. 2015, Barroso et al. 2017, Suassuna et al. 2018), to ensure high lint yields and the competitiveness of Brazilian cotton on the international market. However, most of the released cultivars are RLS-susceptible. Moreover, the prevalent weather conditions (long periods of high air humidity and daytime temperature between 25 and $30^{\circ} \mathrm{C}$ ) throughout the growing season in the cerrado ecosystem are conducive to RLS development (Rathaiah 1977). This must have contributed to proliferate the initial inoculum over years and let the disease become epidemic. Consequently, more fungicide sprays per season in cotton fields are now required, increasing the cost for RLS management.

The cotton breeding program of EMBRAPA (Brazilian Agricultural Research Corporation) was established in 1975 , and since 1989 , cultivars adapted to
Crop Breeding and Applied Biotechnology 20(1): e27242016, 2020 Brazilian Society of Plant Breeding. Printed in Brazil http://dx.doi.org/10.1590/198470332020v20n1c6

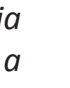


the cerrado have been released. After 2004, efforts were made to develop germplasm resistant to the major diseases, mainly to RLS. For this specific purpose, the breeding program, in partnership with the private sector, was financially supported by FIALGO (Fundo de Incentivo à Cultura do Algodão) and technically by the Fundação Goiás. This paper describes the development of the conventional cotton cultivars BRS 372 and BRS 416 as part of an ongoing effort to create new cotton lines and cultivars with improved yield potential and resistance to one or several diseases, adapted to the Brazilian cerrado.

\section{GENETIC ORIGIN AND DEVELOPMENT}

The cultivars BRS 372 and BRS 416 were developed by hybridization and pedigree selection. BRS 372 was originated from a biparental cross of the cotton cultivars Cacique INTA and CNPA ITA 90. The parent Cacique INTA [Mataco INTA $x$ Guazuncho INTA] has a high gin turnout and is resistant to Bacterial Blight and Cotton Blue Disease. Cultivar CNPA ITA 90 (selected from DP Acala 90) is high-yielding, but susceptible to Bacterial Blight and Cotton Blue Disease. Seeds of the segregating population $F_{2}$ were obtained from the selfed $F_{1}$ hybrid plants. Single plants and rows of progenies were selected by the pedigree method, based on apparent yield potential, high volume instrument (HVI) fiber properties, disease resistance, and the overall plant performance. In the 2001/2002 growing season, in Santa Helena de Goiás - GO, plant '5001' was selected from the segregating $F_{2}$ population. The progenies $\left(F_{2: 3}\right)$ of the selected plant (CNPA GO 2002 -5001) were evaluated and individual plants successively re-selected in the growing seasons of 2002/2003, $2003 / 2004,2004 / 2005,2005 / 2006$ and 2006/2007. In the last, plant '423' was selected and the $F_{8}$ progenies of this plant, denominated CNPA GO 2007-423, were evaluated in the 2007/2008 growing season, in which the CNPA GO 2007423 progenies were bulk-harvested and tested in 2008/2009 as preliminary breeding line $\left(F_{9}\right)$. Line CNPA GO 2007-423 was evaluated as advanced breeding line $\left(\mathrm{F}_{10}\right)$ in the states of Goiás, Bahia, Mato Grosso and Mato Grosso do Sul, in 2009/2010. In the 2010/2011 and 2011/2012 growing seasons, it was evaluated as final breeding line $\left(F_{11}\right)$ in 26 official variety trials for value of cultivation and use (VCU), in the states of Bahia, Goiás, Mato Grosso do Sul, Mato Grosso, Minas Gerais, Maranhão, Piauí, and Rondônia.

Cultivar BRS 416 was derived from a cross between Stoneville 132 [DES 56 x TAMCOT SP37] (Bowman et al. 2006) and Delta Opal [DP $5816 \times$ Sicala 33]. Stoneville 132 is a widely cultivated and Delta Opal a high-yielding cotton cultivar with resistance to bacterial blight and cotton blue disease. 'BRS 416 ' was derived from a single $F_{3: 4}$ progeny row (CNPA GO 2003-1947) after the selection of single plants in the $F_{2}$ and $F_{3}$ generations. Line CNPA GO 2003-1947 showed some variability and in 2006/2007, an individual plant reselection was performed in the $F_{3: 7}$ generation. The progeny CNPA GO 2007-540 ( $\left.F_{8}\right)$ of the selected plant ' 540 ' was evaluated and individual plants were successively re-selected in the 2007/2008, $2008 / 2009$ and $2009 / 2010$ growing seasons. In the last, plant ' 139 ' was selected and the $F_{11}$ progeny, denominated CNPA GO 2010-139, was evaluated in Santa Helena de Goiás, in 2010/2011, selected again and bulk-harvested. In 2011/2012, line CNPA GO 2010-139 ( $\left.F_{12}\right)$ was tested as preliminary breeding line. Line CNPA GO 2010-139 was evaluated as advanced breeding line $\left(F_{13}\right)$ in eight trials, in the states of Goiás, Bahia, Mato Grosso and Mato Grosso do Sul, in the 2011/2012 growing season. Then, it was evaluated as final breeding line $\left(F_{14}\right)$ in 18 VCU trials in Bahia, Goiás, Mato Grosso do Sul, Mato Grosso, Maranhão, Rio Grande do Norte and Ceará, in 2013/2014 and 2014/2015. Parallel to the field performance trials, specific trials without fungicide sprays were carried out to evaluate RLS resistance of both cultivars.

\section{CULTIVAR PERFORMANCE}

The cultivars BRS 372 and BRS 416 are picker-type upland cotton with different growth habits, when grown in Santa Helena de Goiás, GO (lat $17^{\circ} 48^{\prime} \mathrm{S}$, long $50^{\circ} 35^{\prime} \mathrm{W}$, alt $562 \mathrm{~m}$ asl). BRS 372 is medium/tall, has a mean mature plant height of $125 \mathrm{~cm}$, while BRS 416 plants have a medium size $(117 \mathrm{~cm})$, when $50-75 \mathrm{~g}$ ai ha-1 growth regulator (mepiquat chloride and chlormequat chloride) is applied. BRS 372 is a full-season maturing cultivar; first flowers appear about 65 days after emergence (DAE), first bolls open about 110-120 DAE, and total harvest can be performed at 185 DAE. BRS 416 is a midseason cultivar: first flowers appear about 55-60 DAE, first bolls open about 110 - 115 DAE, and, under the environmental conditions of Santa Helena de Goiás and if harvest aid chemicals are applied, total harvest can be performed at 160-165 DAE.

Plants of both cultivars have trichomes on the leaves and main stem. Leaves and bracts ( 7 - 12 lobes) are normally 
shaped and have glands and nectaries. The first reproductive branch is generally inserted at the fifth node. BRS 372 has short fruiting branches, forming an oblique angle with the main stem, while BRS 416 has normal fruit branches with a more perpendicular insertion in relation to the main stem, resulting in cylindrical or cone-shaped plants, respectively. Flowers have cream-colored petals, anthers, and pollen. Full-size green bolls have greater length than width and are broader in the middle. Bolls have five, occasionally four locks. Open bolls resist shattering but are not stormproof and

Table 1. T-test comparison of cottonseed yield (CY $-\mathrm{kg} \mathrm{ha}^{-1}$ ) and lint yield (LY - kg ha ${ }^{-1}$ ) for BRS 372 and FMT 701 (control) in $2010 / 2011$ and 2011/2012 and BRS 416 and FM 910 (control) in the 2013/2014 and 2014/2015 growing seasons

\begin{tabular}{|c|c|c|c|c|c|c|c|c|c|}
\hline & \multicolumn{2}{|c|}{$2010 / 2011$} & \multicolumn{2}{|c|}{$2011 / 2012$} & & \multicolumn{2}{|c|}{$2013 / 2014$} & \multicolumn{2}{|c|}{$2014 / 2015$} \\
\hline & $\mathrm{CY}$ & LY & $\mathrm{CY}$ & LY & & $\mathrm{CY}$ & LY & $\mathrm{CY}$ & LY \\
\hline Error & 439604 & 104225 & 387683 & 74844 & Error & 34309 & 6891 & 67283 & 16790 \\
\hline$d f$ & 612 & 612 & 714 & 714 & $d f$ & 510 & 510 & 306 & 153 \\
\hline $\mathrm{N}$ & 48 & 48 & 56 & 56 & $\mathrm{~N}$ & 40 & 40 & 24 & 12 \\
\hline BRS 372 & 4365 & 1945 & 3837 & 1718 & BRS 416 & 5131 & 2256 & 4810 & 2171 \\
\hline FMT 701 & 3847 & 1653 & 3635 & 1589 & FM 910 & 5076 & 2229 & 4471 & 1994 \\
\hline
\end{tabular}

${ }^{*}$ significant at $5 \% ;{ }^{* *}$ significant at $1 \%$.

Table 2. Means of cottonseed yield (CY - $\mathrm{kg} \mathrm{ha}^{-1}$ ); lint percentage (LP - \%); and lint yield (LY - $\mathrm{kg}^{-1}$ ) of the cotton cultivars BRS 372 and FMT 701 (control), in 26 field trials, in the 2010/11 and 2011/12 growing seasons

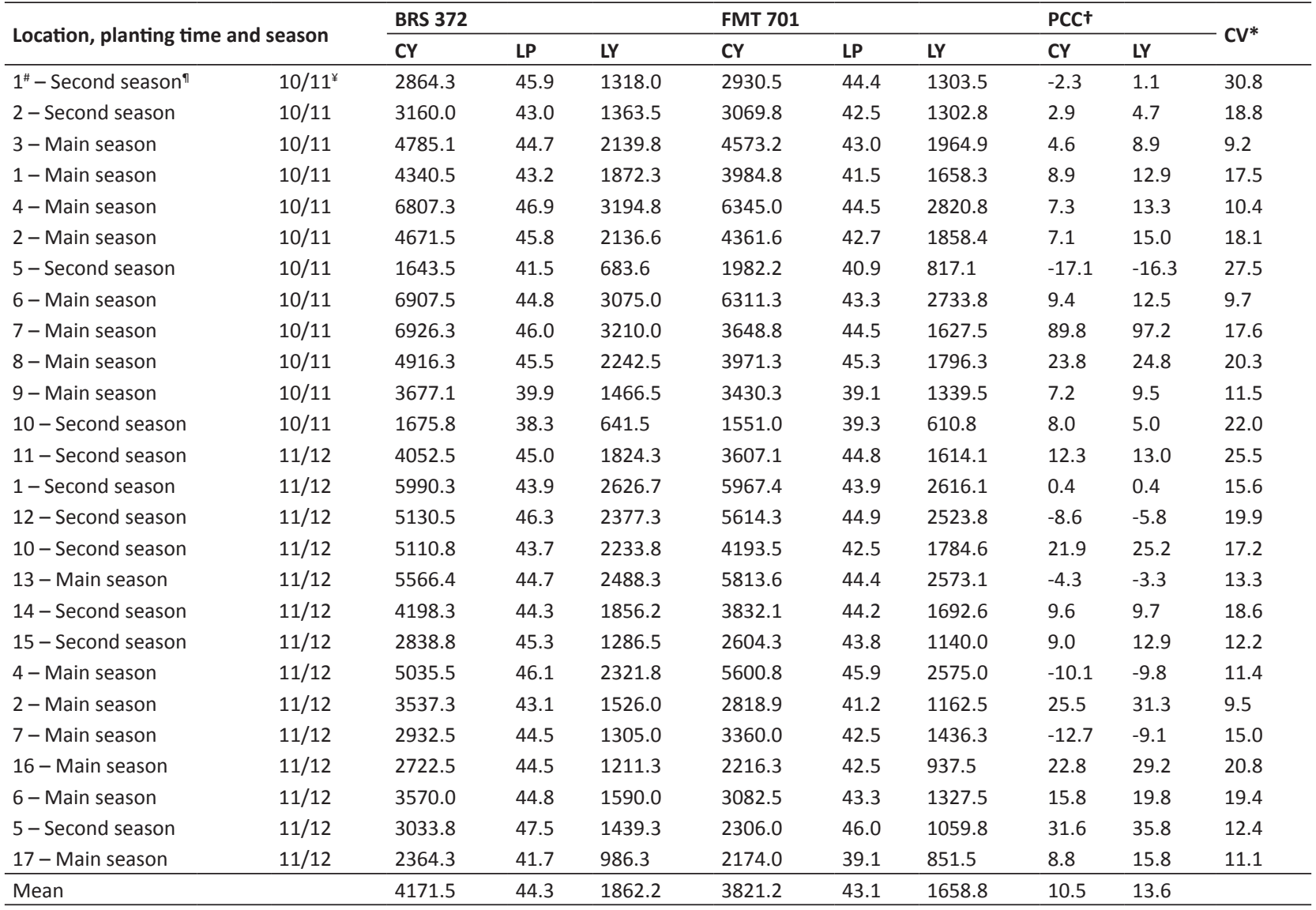

\# 1=Montividiu GO, 2=Santa Helena de Goiás GO, 3= Mineiros GO, 4= Cristalina GO, 5= Chapadão do Sul MS, 6= Correntina BA, 7= São Desidério BA, 8= Formosa do Rio Preto BA, 9= Naviraí MS, 10 = Primavera do Leste MT, 11= Palmeiras de Goiás GO, 12= Ipiranga do Norte MT, 13= Campo Verde MT, 14= Sorriso MT, 15= Sinop MT, 16= Riachão das Neves BA, $17=$ Dourados MS; "Main season = Cotton sown between November and December, Second season = Cotton sown between January and February, after soybean harvest; ${ }^{*} 10 / 11=2010 / 2011,11 / 12=2011 / 2012$. ${ }^{*}$ CV - Coefficient of variation $(\%)$ for cottonseed yield $\left(k^{\prime}\right.$ ha $\left.{ }^{-1}\right)$; + PCC - Percentage in comparison to the control cultivar (increase or decrease). 
are suitable for picker harvesting. Lint and fuzz are white. The mean boll weight of BRS 372 and BRS 416 was 6.0 and $5.2 \mathrm{~g}$, respectively.

Cultivars BRS 372 and BRS 416 have a high resistance level against bacterial blight [caused by Xanthomonas citri subsp. malvacearum], cotton blue disease [caused by Cotton leafroll dwarf virus-CLRDV] and Ramularia leaf spot [caused by Ramulariopsis pseudoglycines]; BRS 372 is moderately resistant to the Fusarium oxysporum f. sp. vasinfectum Meloidogyne incognita complex, while BRS 416 is moderately susceptible; and both are susceptible to ramulosis [caused by Colletotrichum gossypii var. cephalosporioides]. Based on data of cv. BRS 372 from five independent field trials without fungicide spraying, a mean RLS disease score of 1.17 was recorded on a scale from 1 (immune) to 5 (highly susceptible). For cv. BRS 372, fungicide foliar sprays were not necessary to avoid losses caused by ramularia leaf spot (Silva et al. 2017). Cultivar BRS 416 had a mean RLS score of 1.3 across three independent field trials, on the same 1-5 disease score scale.

Disease resistance to cotton blue disease and bacterial blight was confirmed by molecular markers. The fluorochromelabeled SSR primers DC20027 and CIR246 were used for genotyping. These primers were selected because they are physically linked to resistance genes that confer total resistance to blue disease and bacterial blight. Cultivar Delta Opal was used as resistant control. Polymerase chain reactions (PCR) were performed in a multiplex system using the Kit PCR Multiplex (Qiagen), as described by Carvalho et al. (2017). For marker CIR 246, the control (Delta Opal), all BRS 372 samples and $98 \%$ of the BRS 416 samples amplified a 146-bp band, associated with the bacterial blight resistance gene B12 (Xiao et al. 2010). In 2\% of the BRS 416 samples, which were heterozygous but resistant, the 146/156 band pattern was observed. All samples of BRS 372, BRS 416 and Delta Opal (control) amplified a 202-bp band for marker DC 20027. This band pattern is associated with a resistance gene against the blue disease (Fang et al. 2010).

Significant paired comparison t-tests were used to determine significant differences between the test cultivars and control in each growing season. In 2010/2011 (Table 1), BRS 372 yielded significantly more cottonseed (4365 kg ha-1) and lint (1945 kg ha-1) than FMT 701 (3847 and $1653 \mathrm{~kg} \mathrm{ha}^{-1}$, respectively). In 2011/2012, BRS 372 produced significantly more lint than FMT 701 (Table 1). Averaged across the 26 VCU trials in central and northeastern Brazil, in 2010/2011 and

Table 3. Means of cottonseed yield (CY - $\mathrm{kg} \mathrm{ha}^{-1}$ ); lint percentage (LP - \%); and lint yield (LY - $\mathrm{kg}^{-1}$ ) of the cotton cultivars BRS 416 and FM 910 (control), in 18 field trials, in the 2013/14 and 2014/15 growing seasons

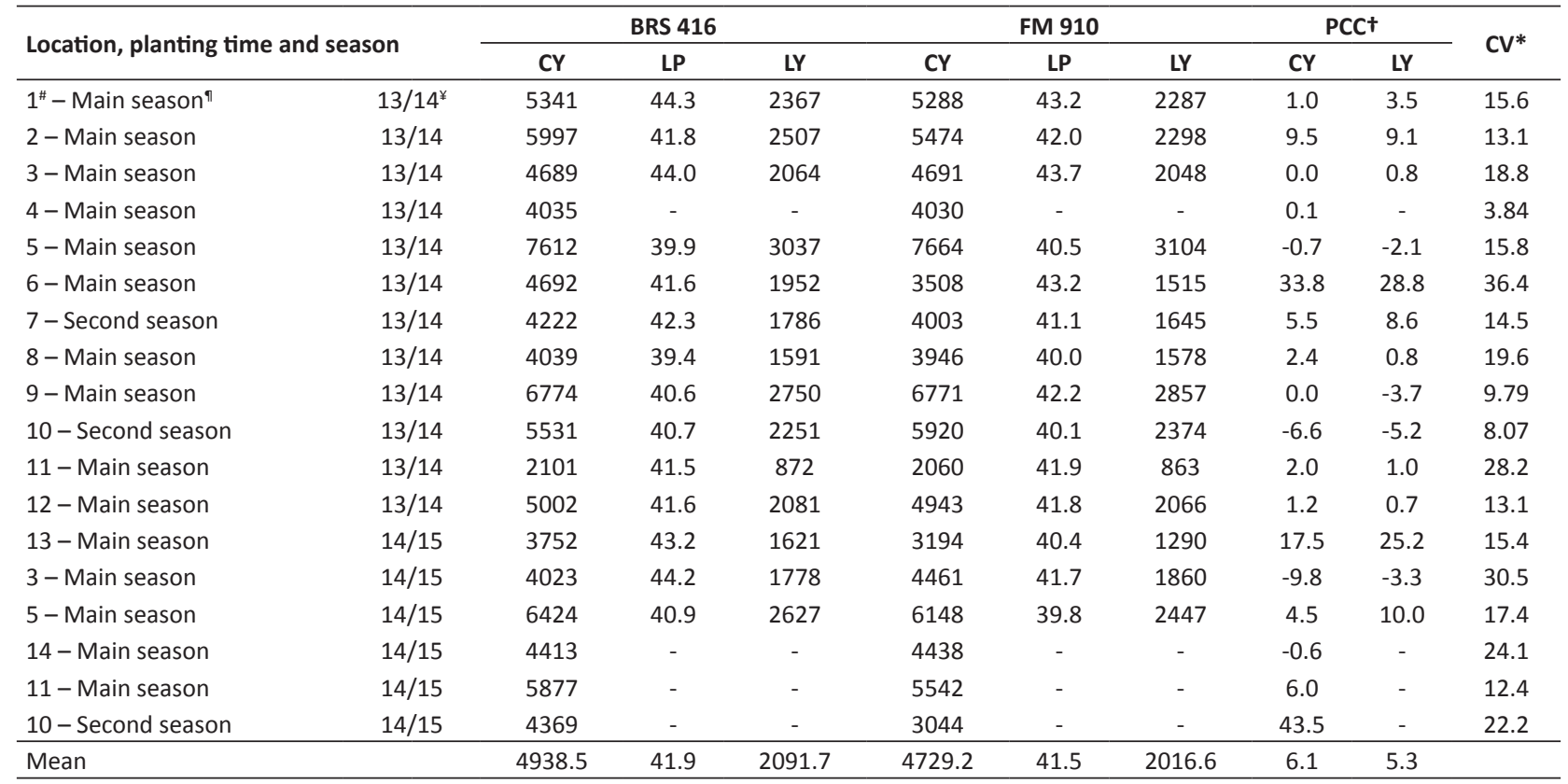

\# 1= Correntina BA, 2= São Desidério BA, 3= Riachão das Neves BA, 4= Mata Roma MA, 5= Apodi RN, 6= Missão velha CE, 7= Mineiros GO, 8= Santa Helena de Goiás GO, 9= Cristalina GO, 10= Primavera do Leste MT, 11= Campo Verde MT, 12= Chapadão do Sul MS, 13= Luís Eduardo Magalhães BA, 14= Santo Antônio de Goiás GO; "Main season $=$ Cotton sown between November and December, Second season $=$ Cotton sown between January and February, after soybean harvest; ${ }^{*} 13 / 14=2013 / 2014,14 / 15=$ $2014 / 2015$. * CV - Coefficient of variation (\%) for cottonseed yield ( $\left.\mathrm{kg} \mathrm{ha}^{-1}\right)$; † PCC - Percentage in comparison to the control cultivar (increase or decrease). 
BRS 372 and BRS 416: high-yielding cotton cultivars with multiple disease resistance

Table 4. Agronomic traits and fiber quality of BRS 372, BRS 416, FMT 701 (control), and FM 910 (control)

\begin{tabular}{|c|c|c|c|c|}
\hline Traits & BRS 372 & BRS 416 & FMT 701 & FM 910 \\
\hline First flower (DAE) ${ }^{*}$ & 65 & $55-60$ & - & - \\
\hline First open boll (DAE) ${ }^{*}$ & $110-120$ & $110-115$ & - & - \\
\hline Boll weight $(\mathrm{g})^{\text {a }}$ & 6.0 & 5.2 & - & - \\
\hline Weight of 100 seeds $(\mathrm{g})^{\text {a }}$ & 8.9 & 8.2 & - & - \\
\hline Fiber length (UHML) (mm) a & 29.8 & 29.7 & 29.0 & 29.5 \\
\hline Uniformity index (ML/UHML - \%) ${ }^{\text {a }}$ & 83.5 & 85.2 & 84.0 & 84.4 \\
\hline Elongation (\%) ${ }^{\text {a }}$ & 6.6 & 6.3 & 6.3 & 6.2 \\
\hline Reflectance - Rd (\%) ${ }^{a}$ & 77.5 & 76.7 & 78.3 & 79.4 \\
\hline Yellowness $(+b)^{a}$ & 8.0 & 7.9 & 7.5 & 8.9 \\
\hline Short fiber index (\%) ${ }^{a}$ & 7.2 & 7.0 & 7.1 & 6.5 \\
\hline Cotton leafroll dwarf virus $(C L R D V)^{b}$ & 0.0 & 0.0 & 0.0 & 0.0 \\
\hline Ramulosis c,e & 3.7 & 2.5 & - & 2.6 \\
\hline
\end{tabular}

* Data recorded in Santa Helena de Goiás (lat 17 48' 15” S, long 50 35’ 43” W, alt 562 m asl) - GO.

a Means of 26 (BRS 372 and FMT 701) or of 18 (BRS 416 and FM 910) field trials in several environments (States of Goiás, Bahia, Mato Grosso, Mato Grosso do Sul, Maranhão, Rio Grande do Norte and Ceará); ' Incidence (\%) of plants with cotton blue disease symptoms - data of two assays without control of virus vector (Aphis gossypii), confirmed by the SNP marker (Fang et al. 2010); ${ }^{\mathrm{c}}$ Disease severity (grades from 1 = resistant to $5=$ highly susceptible); ${ }^{\mathrm{d}}$ For bacterial blight, resistance confirmed by the SNP marker (Xiao et al. 2010); e Data of plants artificially inoculated with Colletotrichum gossypii var. cephalosporioides in a field trial.

2011/2012, BRS 372 produced $1862.2 \mathrm{~kg}$ lint per hectare, i.e., 13.6\% higher lint yield than the control cultivar FMT 701. Higher lint productivity is related to the lint percentage. BRS 372 had a mean lint percentage of $44.3 \%$ (ranging from 38.3 to $47.5 \%$ ) across the trials (Table 2 ). The HVI measurements indicated that the cultivar has the desirable physical properties of a medium fiber length cultivar: mean micronaire reading of 4.4; mean fiber length (UHML) 29.8mm; mean relative strength $29.5 \mathrm{gf} \mathrm{tex}^{-1}$; reflectance of $77.5 \%$; yellowness (+b) 8.0 and short fiber index 7.2 (Table 4).

The evaluations in 18 VCU field trials in central and northeastern Brazil in 2013/2014 and 2014/2015 showed that cultivar BRS 416 produced 6.1\% more cottonseed and a 5.3\% higher lint yield than cultivar FM 910. In 2013/2014, there were no significant differences between BRS 416 and FM 910 for cottonseed yield and lint yield (Table 1). However, in 2014/2015, BRS 416 yielded significantly more cottonseed (4810 kg ha-1) and lint ( $2171 \mathrm{~kg} \mathrm{ha}^{-1}$ ) than FM 910 (4471 and $1994 \mathrm{~kg} \mathrm{ha}^{-1}$, respectively). The mean lint percentage was $41.9 \%$ for cultivar BRS 416 and $41.5 \%$ for FM 910 (Table 3). Cultivar BRS 416 is a medium staple upland cotton, according to the HVI fiber properties: micronaire reading 3.9 - 4.8 ; fiber length (UHML) 27.6 - $31.2 \mathrm{~mm}$; relative strength 27.4 - 29.2 gf tex $^{-1}$; reflectance 71.5 - 80.5\%; yellowness (+b) 7.3 - 8.8; short fiber index 5.1 - 8.7. The mean data of fiber quality of 18 field trials are summarized in Table 4.

\section{SEED MAINTENANCE AND DISTRIBUTION}

Cultivars BRS 372 and BRS 416 are protected (certificates no. 20140173 and 20170145, respectively) by the Brazilian Ministry of Agriculture, Livestock and Food Supply. Genetic seed is available at Embrapa Cotton.

\section{REFERENCES}

Barroso PAV, Suassuna ND, Pedrosa MB, Morello CL, Silva JL, Lamas FM and Bogiani JC (2017) BRS 368RF: A glyphosate tolerant, midseason upland cotton cultivar for Northeast and North Brazilian savanna. Crop Breeding and Applied Biotechnology 17: 388-402.

Bowman DT, Gutierrez OA, Percy RG, Calhoun DS and May OL (2006) Pedigrees of upland and pima cotton cultivars released between 1970 and 2005. Mississippi Agricultural \& Forestry Experiment
Station, Starkville, 58p.

Carvalho LP, Farias FJC, Rodrigues JIS, Suassuna ND and Teodoro PE (2017) Genetic diversity among exotic cotton accessions as for qualitative and quantitative traits. Genetics and Molecular Research 16: 1-10.

Fang DD, Xiao J, Canci PC and Cantrell RG (2010) A new SNP haplotype associated with blue disease resistance gene in cotton (Gossypium hirsutum L.). Theoretical and Applied Genetics 120: 943-953.

Ferreira Filho JBS and Alves LRA (2007) Aspectos econômicos do algodão 
no cerrado. Algodão no cerrado do Brasil. ABRAPA, Brasília, p. 53-89.

Morello CL, Suassuna ND, Farias FJC, Lamas FM, Pedrosa MB, Ribeiro JL, Godinho VPC and Freire EC (2010) BRS 293: A midseason highyielding upland cotton cultivar for Brazilian savanna. Crop Breeding and Applied Biotechnology 10: 180-182.

Morello CL, Pedrosa MB, Suassuna ND, Lamas FM, Chitarra LG, Silva JL, Andrade FP, Barroso PAV, Ribeiro JL, Godinho VPC and Lanza MA (2012) BRS 336: a high-quality fiber upland cotton cultivar for Brazilian savanna and semi-arid conditions. Crop Breeding and Applied Biotechnology 12: 92-95.

Morello CL, Suassuna ND, Barroso PAV, Silva JL, Ferreira ACB, Lamas FM, Pedrosa MB, Chitarra LG, Ribeiro JL, Godinho VPC and Lanza MA (2015) BRS 369RF and BRS 370RF: Glyphosate tolerant, high-yielding upland cotton cultivars for central Brazilian savanna. Crop Breeding and Applied Biotechnology 15: 290-294.

Silva JC, Suassuna ND and Bettiol W (2017) Management of Ramularia leaf spot on cotton using integrated control with genotypes, a fungicide and Trichoderma asperellum. Crop Protection 94: 28-32.

Silva JC, Bettiol W and Suassuna ND (2019) Ramularia leaf spot: an emergent disease of cotton in Brazil. Tropical Plant Pathology 44: 473-482.

Silva Neto SB, Pereira AF, Morello CL and Suassuna ND (2016) Melhoramento clássico e biotecnologia visando à superação de desafios. In Piccoli GV, Dancin E and Lopes MA. Desafios do Cerrado: Como sustentar a expansão da produção com produtividade e competitividade. Associação Mato-grossense dos Produtores de Algodão, Cuiabá, p. 215-252.

Rathaiah Y (1977) Spore germination and mode of action of cotton infection by Ramularia areola. Phytopathology 67: 351-357.

Suassuna ND, Morello CL, Pedrosa MB, Barroso PAV, Silva JL, Suassuna TMF, Perina FJ, Sofiatti V, Magalhães FOC and Farias FJC (2018) BRS 430 B2RF and BRS 432 B2RF: Insect resistant and glyphosatetolerant high-yielding cotton cultivars. Crop Breeding and Applied Biotechnology 18: 221-225.

Xiao J, Fang DD, Bhatti M, Hendrix B and Cantrell RG (2010) A SNP haplotype associated with a gene resistant to Xanthomonas axonopodis pv. malvacearum in upland cotton (Gossypium hirsutum L.). Molecular Breeding 25: 593-602. 